\title{
DENTAL CARIES PREVALENCE IN CHILDREN UP TO 36 MONTHS OF AGE ATTENDING DAYCARE CENTERS IN MUNICIPALITIES WITH DIFFERENT WATER FLUORIDE CONTENT
}

\author{
Ana Valéria Pagliari TIANO ${ }^{1}$, Suzely Adas Saliba MOIMAZ², Orlando SALIBA ${ }^{3}$, Nemre Adas SALIBA ${ }^{3}$
}

\author{
1- DDS, MSc, Graduate Student, Preventive and Community Dentistry Program, Dental School of Araçatuba, São Paulo State University, Araçatuba, \\ SP, Brazil. \\ 2- DDS, MSc, PhD, Associate Professor, Preventive and Community Dentistry Program, Dental School of Araçatuba, São Paulo State University, \\ Araçatuba, SP, Brazil. \\ 3- DDS, MSc, PhD, Full Professor, Preventive and Community Dentistry Program, Dental School of Araçatuba, São Paulo State University, Araçatuba, \\ SP, Brazil.
}

Corresponding address: Dra. Ana Valéria Tiano - R. José Bonifácio, 1193, Vila Mendonça, 16015-150 Araçatuba, SP, Brazil - Phone: 55-18-36363249 e-mail: anapagliari@yahoo.com.br

Received: March 6, 2008 - Modification: April 5, 2008 - Accepted: April 14, 2008

\begin{abstract}
$T_{\text {his study determined the prevalence of cavitated caries lesions (CCL) and early childhood caries (ECC), and the contribution of }}$ some variables in children up to 36 months of age attending daycare centers in municipalities with different fluoride levels in the water supply: AFC (adequate fluoride content) and LFC (low fluoride content). After approval of the Ethics Committee, the parents were interviewed. The children were clinically examined using the same codes and criteria established by the WHO (World Health Organization) and the ADA (American Dental Association). Fisher's exact test $(\mathrm{p}<0.05)$ was applied for statistical analysis of data. The dmft indices calculated in the LFC and AFC municipalities were 0.57 and 0.68 , respectively. Considering all children examined, $17.6 \%$ presented CCL and 33.8\% ECC. The economic classification, mother's education level and duration of breastfeeding were considered statistically significant with regards to CCL prevalence. The age group, duration of the habit of drinking milk before bedtime and age at which oral hygiene started were considered statistically significant with regards to ECC prevalence.
\end{abstract}

Key words: Oral health. Dental caries. Early childhood caries.

\section{INTRODUCTION}

The expression "early childhood caries" (ECC) is used to refer to any stage of caries lesion in any surface of primary teeth of children up to 71 months of age ${ }^{7,11}$.

The national survey carried out in $2002-2003^{2}$ revealed a caries prevalence of $26.8 \%$ among 18-36-month-old Brazilian children, and $23.2 \%$ among the inhabitants of the southeastern region of the country. Using the criteria proposed by the World Health Organization (WHO) ${ }^{19}$, in which a tooth is considered carious only if there is a visible evidence of a cavity, this national survey included data referring only to cavitated caries lesions (CCL) and noncavitated caries lesions were not considered. Although the inclusion of the initial stages of caries in epidemiological surveys is questionable because of the possibility of lesion reversal, its identification is socially relevant, as it gives the opportunity of early intervention ${ }^{1,7,18}$.
This study aimed to determine the prevalence of CCL and ECC, evaluating the contribution of different variables in its occurrence in children up to 36 months of age attending public daycare centers in municipalities with different fluoride concentration in the water supply.

\section{MATERIALAND METHODS}

The study was conducted with children up to 36 months of age in public daycare centers of two municipalities located in the southeastern region of Brazil: Clementina, in which fluoride is not added to the water supply and the natural fluoride content is lower than $0.40 \mathrm{mg} \mathrm{F} / \mathrm{L}^{17}$ (low fluoride content - LFC), and Gabriel Monteiro, in which fluoride is added to the water supply in an optimal concentration that ranges from 0.60 to $0.75 \mathrm{mg} \mathrm{F} / \mathrm{L}^{17}$ (adequate fluoride content - AFC). 
In the daycare centers, the children take cow's milk from nursing bottles sweetened with sugar, and are fed sugarcontaining snacks like biscuits and sweetened drinks (juices and tea) daily. Neither the caregivers were aware of the need to brush the children's teeth, nor the daycare centers offered preventive oral health programs.

After approval by the Research Ethics Committee of the São Paulo State University, the parents were invited to participate in the survey and, upon acceptance, they were interviewed about the following issues: the economic classification of the family, using the classification proposed by the Brazilian Association of Research Companies, the parents' age and educational level, nursing habits, consumption of water from the public water supply, use of dentifrice, access to dental assistance and background knowledge of oral health care. Exclusion criteria were the refusal to answer the questionnaire, absence of parental consent for clinical examination of the children or absence of teeth in the child.

Clinical examinations were carried out under natural light, by a single examiner, trained and calibrated, who assumed a knee-to-knee position and was helped by an assistant and by a note taker. Oral hygiene quality was assessed using the Greene and Vermillion index ${ }^{9}$. All fully erupted teeth were included in the evaluation. A plaquedisclosing solution was applied to the buccal and palatal/ lingual surfaces. The dental crowns were examined two days later for the presence of caries lesions. For CCL, the same codes and criteria established by the $\mathrm{WHO}^{19}$ were applied. Therefore, a tooth was considered carious only if there was a visible evidence of a cavity. Since there was a need to include early caries lesions in this study, the criteria proposed by the American Dental Association (ADA) ${ }^{7}$ for ECC were used. Therefore, in pits and fissures, a distinct chalky white enamel directly adjacent to or into a pit or fissure or a light to dark brown discolored area was considered ECC, while in smooth surfaces, a distinct chalky white enamel adjacent or close to the gingival margin was considered ECC.

The data were processed and analyzed using Epi-info software program. The means and standard deviation (mean \pm SD) of the examined children's ages and the means, standard deviation and $95 \%$ confidence interval (mean \pm $\mathrm{SD} ; 95 \% \mathrm{CI}$ ) of the dmft and dmfs were calculated. Fisher's exact test $(\mathrm{a}=0.05)$ was applied to access the association between variables studied, using BiosEstat 4.0 software program.

\section{RESULTS}

From a total of 88 children, $68(77.3 \%)$ were examined. In the LFC municipality, 38 children aged 8 to 36 months $(23.70 \pm 8.30)$ participated in the study, while in the AFC municipality, 30 children aged 8 to 36 months $(23.63 \pm 9.28)$ were examined.

The dmft and dmfs indices calculated for the study sample are presented in Table 1.

Considering all children examined in this study, 17.6\% presented CCL and $33.8 \%$ presented ECC. The association between CCL and the studied variables is presented in Table 2. Fisher's exact test revealed the existence of statistically significant differences $(\mathrm{p}<0.05)$ regarding the economic classification, mother's educational level and duration of breastfeeding. Higher prevalence of CCL was associated with lower economic classification, lower mother's education level ( 8 years of study) and higher duration of breastfeeding ( $>12$ months of age).

Table 3 shows the prevalence of ECC. Fisher's exact test revealed statistically significant differences $(\mathrm{p}<0.05)$ regarding to age group, duration of the habit of drinking milk before bedtime, and age at which oral hygiene started. Higher prevalence of ECC was associated with the older age group, higher duration of the bedtime feeding habit $(>12$ months of age), and later start of oral hygiene (>12 months of age).

\section{DISCUSSION}

Although a reduction in the prevalence of caries in preschoolers has been observed ${ }^{12}$, ECC is still considered a public health problem because its a predisposing factor to the occurrence of caries disease in the permanent dentition, impairs normal feeding, leading to growth alterations, causes pain and discomfort, and may bring communication and psychosocial problems, affecting the child's life quality ${ }^{4,6,10}$.

Considering only the 18-36-month age group, $22.2 \%$ of the children presented CCL (Table 2), which is a higher

TABLE 1- Mean, standard deviation and 95\% confidence interval of the dmf-t and dmf-s indices, 2006

\begin{tabular}{llcr} 
Municipality & Age (months) & mean \pm SD $(95 \%$ Cl) \\
& & dmf-t & dmf-s \\
\hline \multirow{2}{*}{ LFC } & $18-36$ & $0.84 \pm 2.00(0.36-1.31)$ & $1.39 \pm 4.70(0.27-2.50)$ \\
& 36 & $0.68 \pm 1.83(0.10-1.27)$ & $1.13 \pm 4.26(0.00-2.49)$ \\
AFC & $18-36$ & $0.74 \pm 2.16(0.23-1.25)$ & $1.30 \pm 4.04(0.34-2.26)$ \\
& $\leq 36$ & $0.57 \pm 1.91(0.00-1.25)$ & $1.00 \pm 3.56(0.00-2.27)$ \\
Total & $18-36$ & $0.80 \pm 2.05(0.31-1.28)$ & $1.35 \pm 4.39(0.31-2.39)$ \\
& $\leq 36$ & $0.63 \pm 1.85(0.19-1.07)$ & $1.07 \pm 3.94(0.14-2.01)$
\end{tabular}

$\mathrm{AFC}=$ with adequate fluoride content; LFC = with low fluoride content. 
TABLE 2- CCL prevalence regarding the studied variables

\begin{tabular}{|c|c|c|c|c|c|c|c|c|}
\hline \multicolumn{2}{|c|}{ Variables } & \multicolumn{2}{|c|}{ with caries } & \multicolumn{2}{|c|}{ caries free } & \multicolumn{2}{|c|}{ Total } & \multirow[t]{2}{*}{$\mathbf{p}$} \\
\hline & & $\mathbf{n}$ & $\%$ & $\mathbf{N}$ & $\%$ & $\mathbf{n}$ & $\%$ & \\
\hline Age group & Up to 17 & 0 & 0 & 14 & 100.0 & 14 & 100.0 & 0.059 \\
\hline (months) & 18 to 36 & 12 & 22.2 & 42 & 77.8 & 54 & 100.0 & \\
\hline Economic & High & 4 & 9.3 & 39 & 90.7 & 43 & 100.0 & $0.044^{*}$ \\
\hline classification ${ }^{\star \star}$ & Low & 8 & 32.0 & 17 & 68.0 & 25 & 100.0 & \\
\hline \multirow{2}{*}{$\begin{array}{c}\text { Father's education level } \\
\text { (years of study) }\end{array}$} & Up to 8 & 10 & 23.3 & 33 & 76.7 & 43 & 100.0 & 0.187 \\
\hline & 9 or more & 2 & 8.0 & 23 & 92.0 & 25 & 100.0 & \\
\hline \multirow{2}{*}{$\begin{array}{l}\text { Mother's education level } \\
\text { (years of study) }\end{array}$} & Up to 8 & 10 & 29.4 & 24 & 70.6 & 34 & 100.0 & $0.013^{*}$ \\
\hline & 9 or more & 2 & 5.9 & 32 & 94.1 & 34 & 100.0 & \\
\hline \multirow{2}{*}{$\begin{array}{c}\text { Father's age } \\
\text { (years) }\end{array}$} & Up to 25 & 3 & 10.0 & 27 & 90.0 & 30 & 100.0 & 0.204 \\
\hline & 26 or more & 9 & 23.7 & 29 & 76.3 & 38 & 100.0 & \\
\hline \multirow{2}{*}{$\begin{array}{l}\text { Mother's age } \\
\quad \text { (years) }\end{array}$} & Up to 25 & 4 & 11.1 & 32 & 88.9 & 36 & 100.0 & 0.203 \\
\hline & 26 or more & 8 & 25.0 & 24 & 75.0 & 32 & 100.0 & \\
\hline \multirow{2}{*}{$\begin{array}{l}\text { Duration of breast } \\
\text { feeding (months) }\end{array}$} & Up to 12 & 6 & 12.8 & 41 & 87.2 & 47 & 100.0 & $0.022^{*}$ \\
\hline & 13 or more & 6 & 42.9 & 8 & 57.1 & 14 & 100.0 & \\
\hline \multirow{2}{*}{$\begin{array}{l}\text { Duration of bedtime } \\
\text { feeding (months) }\end{array}$} & Up to 12 & 0 & 0 & 14 & 100.0 & 14 & 100.0 & 0.059 \\
\hline & 13 or more & 12 & 22.2 & 42 & 77.8 & 54 & 100.0 & \\
\hline \multirow{2}{*}{$\begin{array}{l}\text { Duration of nighttime } \\
\text { feeding (months) }\end{array}$} & Up to 12 & 3 & 11.1 & 24 & 88.9 & 27 & 100.0 & 0.197 \\
\hline & 13 or more & 9 & 26.5 & 25 & 73.5 & 34 & 100.0 & \\
\hline \multirow[t]{2}{*}{ Oral hygiene } & Yes & 10 & 17.9 & 46 & 82.1 & 56 & 100.0 & 1.000 \\
\hline & No & 2 & 16.7 & 10 & 83.3 & 12 & 100.0 & \\
\hline \multirow{2}{*}{$\begin{array}{c}\text { Frequency of oral } \\
\text { hygiene (times a day) }\end{array}$} & None / occasionally & 5 & 17.9 & 23 & 82.1 & 28 & 100.0 & 1.000 \\
\hline & At least 1 & 7 & 17.5 & 33 & 82.5 & 40 & 100.0 & \\
\hline \multirow{2}{*}{$\begin{array}{c}\text { Age at which oral } \\
\text { hygiene started (months) }\end{array}$} & Up to 11 & 2 & 8.7 & 21 & 91.3 & 23 & 100.0 & 0.172 \\
\hline & 12 or more & 8 & 24.2 & 25 & 75.8 & 33 & 100.0 & \\
\hline \multirow[t]{2}{*}{ Hygiene classification } & Good or fair & 8 & 20.0 & 32 & 80.0 & 40 & 100.0 & 0.748 \\
\hline & Poor & 4 & 14.3 & 24 & 85.7 & 28 & 100.0 & \\
\hline \multirow[t]{2}{*}{ Use of dentifrice } & Yes & 9 & 18.8 & 39 & 81.3 & 48 & 100.0 & 1.000 \\
\hline & No & 3 & 15.0 & 17 & 85.0 & 20 & 100.0 & \\
\hline Age at which oral & Up to 11 & 2 & 28.6 & 5 & 71.4 & 7 & 100.0 & 0.600 \\
\hline hygiene started (months) & 12 or more & 7 & 17.1 & 34 & 82.9 & 41 & 100.0 & \\
\hline Fluoride content & AFC & 3 & 10.0 & 27 & 90.0 & 30 & 100.0 & 0.204 \\
\hline on water & LFC & 9 & 23.7 & 29 & 76.3 & 38 & 100.0 & \\
\hline \multirow[t]{2}{*}{ Access to dental service } & Yes & 3 & 37.5 & 5 & 62.5 & 8 & 100.0 & 0.141 \\
\hline & No & 9 & 15.0 & 51 & 85.0 & 60 & 100.0 & \\
\hline \multirow{2}{*}{$\begin{array}{l}\text { Instructions about oral } \\
\text { health care }\end{array}$} & Yes & 3 & 15.8 & 16 & 84.2 & 19 & 100.0 & 1.000 \\
\hline & No & 9 & 18.4 & 40 & 81.6 & 49 & 100.0 & \\
\hline
\end{tabular}

* $(p<0.05)$; ** economic classification proposed by the Brazilian Association of Research Companies. Average monthly family income: High - U\$ 213 to 1,402 - classes B and C; Low - U\$ 103 to 212 - classes D and E.; AFC = with adequate fluoride content; LFC = with low fluoride content.

incidence than that reported by Brandão, et al. ${ }^{1}(2006)$. However, the children taking part in that study had had an easy access to dental care, which demonstrates the importance of early dental care. When data were collected from children who had not had access to dental care, such as those taking part in the present study, CCL prevalence is the same or higher ${ }^{2,13,16}$.

As reported elsewhere ${ }^{4,13,15}$, in the present study, dental caries had an early onset in the examined children. Caries prevalence increased with age and ECC prevalence presented a statistical significance $(\mathrm{p}<0.05)$ with regards to age group (Table 3 ). This can be explained by the so called "window of infectivity", defined as that period between the ages of 16 and 32 months, in which the children is infected with Streptococcus mutans, although some studies indicate that infection may occur at a younger age, even before 14 months of age $\mathrm{e}^{14}$.

In the present study, the parents were only asked about 
TABLE 3- ECC prevalence regarding the studied variables

\begin{tabular}{|c|c|c|c|c|c|c|c|c|}
\hline \multicolumn{2}{|c|}{ Variables } & \multicolumn{2}{|c|}{ with caries } & \multicolumn{2}{|c|}{ caries free } & \multicolumn{2}{|c|}{ Total } & \multirow[t]{2}{*}{$\mathbf{p}$} \\
\hline & & $\mathbf{n}$ & $\%$ & $\mathbf{N}$ & $\%$ & $\mathbf{n}$ & $\%$ & \\
\hline Age group & Up to 17 & 0 & 0 & 14 & 100.0 & 14 & 100.0 & $0.001^{*}$ \\
\hline (months) & 18 to 36 & 23 & 42.6 & 31 & 57,4 & 54 & 100.0 & \\
\hline Economic & High & 12 & 27.9 & 31 & 72.1 & 43 & 100.0 & 0.195 \\
\hline classification** & Low & 11 & 44.0 & 14 & 56.0 & 25 & 100.0 & \\
\hline \multirow{2}{*}{$\begin{array}{l}\text { Father's education level } \\
\text { (years of study) }\end{array}$} & Up to 8 & 16 & 37.2 & 27 & 62.8 & 43 & 100.0 & 0.596 \\
\hline & 9 or more & 7 & 28.0 & 18 & 72.2 & 25 & 100.0 & \\
\hline \multirow{2}{*}{$\begin{array}{c}\text { Mother's education level } \\
\text { (years of study) }\end{array}$} & Up to 8 & 13 & 38.2 & 21 & 61.8 & 34 & 100.0 & 0.609 \\
\hline & 9 or more & 10 & 29.4 & 24 & 70.6 & 34 & 100.0 & \\
\hline \multirow{2}{*}{$\begin{array}{c}\text { Father's age } \\
\text { (years) }\end{array}$} & Up to 25 & 6 & 30.0 & 14 & 70.0 & 20 & 100.0 & 0.782 \\
\hline & 26 or more & 17 & 35.4 & 31 & 64.6 & 48 & 100.0 & \\
\hline \multirow{2}{*}{$\begin{array}{l}\text { Mother's age } \\
\quad \text { (years) }\end{array}$} & Up to 25 & 12 & 33.3 & 24 & 66.7 & 36 & 100.0 & 1.000 \\
\hline & 26 or more & 11 & 34.4 & 21 & 65.6 & 32 & 100.0 & \\
\hline \multirow{2}{*}{$\begin{array}{l}\text { Duration of breast } \\
\text { feeding (months) }\end{array}$} & Up to 12 & 17 & 36.2 & 30 & 63.8 & 47 & 100.0 & 0.756 \\
\hline & 13 or more & 6 & 42.9 & 8 & 57.1 & 14 & 100.0 & \\
\hline \multirow{2}{*}{$\begin{array}{l}\text { Duration of bedtime } \\
\text { feeding (months) }\end{array}$} & Up to 12 & 0 & 0 & 14 & 100.0 & 14 & 100.0 & $0.001^{*}$ \\
\hline & 13 or more & 23 & 42.6 & 31 & 57.4 & 54 & 100.0 & \\
\hline \multirow{2}{*}{$\begin{array}{l}\text { Duration of nighttime } \\
\text { feeding (months) }\end{array}$} & Up to 12 & 7 & 25.9 & 20 & 74.1 & 27 & 100.0 & 0.579 \\
\hline & 13 or more & 12 & 35.3 & 22 & 64.7 & 34 & 100.0 & \\
\hline \multirow[t]{2}{*}{ Oral hygiene } & Yes & 19 & 33.9 & 37 & 66.1 & 56 & 100.0 & 1.000 \\
\hline & No & 4 & 33.3 & 8 & 66.7 & 12 & 100.0 & \\
\hline \multirow{2}{*}{$\begin{array}{c}\text { Frequency of oral } \\
\text { hygiene (times a day) }\end{array}$} & None / occasionally & 9 & 32.1 & 19 & 67.9 & 28 & 100.0 & 1.000 \\
\hline & At least 1 & 14 & 35.0 & 26 & 65.0 & 40 & 100.0 & \\
\hline Age at which oral & Up to 11 & 4 & 17.4 & 19 & 82.6 & 23 & 100.0 & $0.044^{*}$ \\
\hline \multirow{3}{*}{$\begin{array}{l}\text { hygiene started (months) } \\
\text { Hygiene classification }\end{array}$} & 12 or more & 15 & 45.5 & 18 & 54.5 & 33 & 100.0 & \\
\hline & Good or fair & 15 & 37.5 & 25 & 62.5 & 40 & 100.0 & 0.603 \\
\hline & Poor & 8 & 28.6 & 20 & 71.4 & 28 & 100.0 & \\
\hline \multirow[t]{2}{*}{ Use of dentifrice } & Yes & 18 & 37.5 & 30 & 62.5 & 48 & 100.0 & 0.405 \\
\hline & No & 5 & 25.0 & 15 & 75.0 & 20 & 100.0 & \\
\hline \multirow{2}{*}{$\begin{array}{c}\text { Age at which oral } \\
\text { hygiene started (months) }\end{array}$} & Up to 11 & 2 & 28.6 & 5 & 71.4 & 7 & 100.0 & 0.696 \\
\hline & 12 or more & 16 & 39.0 & 25 & 61.0 & 41 & 100.0 & \\
\hline \multirow{2}{*}{$\begin{array}{c}\text { Fluoride content } \\
\text { on water }\end{array}$} & AFC & 8 & 26.7 & 22 & 73.3 & 30 & 100.0 & 0.310 \\
\hline & LFC & 15 & 39.5 & 23 & 60.5 & 38 & 100.0 & \\
\hline \multirow[t]{2}{*}{ Access to dental service } & Yes & 4 & 50.0 & 4 & 50.0 & 8 & 100.0 & 0.428 \\
\hline & No & 19 & 31.7 & 41 & 68.3 & 60 & 100.0 & \\
\hline \multirow{2}{*}{$\begin{array}{l}\text { Instructions about oral } \\
\text { health care }\end{array}$} & Yes & 6 & 31.6 & 13 & 68.4 & 19 & 100.0 & 0.966 \\
\hline & No & 17 & 34.7 & 32 & 65.3 & 49 & 100.0 & \\
\hline
\end{tabular}

* $(\mathrm{p}<0.05) ;{ }^{* *}$ economic classification proposed by the Brazilian Association of Research Companies. Average monthly family income: High - U\$ 213 to 1,402 - classes B and C; Low - U\$ 103 to 212 - classes D and E.; AFC = with adequate fluoride content; LFC = with low fluoride content.

nursing habits, but it is important to mention that the children consumed sugar-containing snacks daily in the daycare centers.

The relationship between caries and milk feeding is controversial in the literature. In the present study, the children who were breastfed beyond 12 months of age presented higher prevalence of CCL $(\mathrm{p}<0.05)$, confirming the findings of Dini, et al. ${ }^{6}(2000)$. In children that presented ECC, prolongation of the habit of milk feeding at bedtime beyond the age of 12 months was considered statistically significant $(\mathrm{p}<0.05)$, corroborating the findings of Milgrom, et al. ${ }^{13}$ (2000). Nighttime milk feeding, mainly bottle-feeding, seems to be associated with the beginning of colonization of the baby's mouth ${ }^{10}$, presence of a large number of cariogenic microorganisms ${ }^{13,14}$, increase in sucrose consumption, mainly by baby bottle, and reduction in oral hygiene practices ${ }^{8}$.

Children who started oral hygiene earlier presented a 
lower prevalence of ECC $(\mathrm{p}<0.05)$, which corroborates the findings of previous studies ${ }^{4,5}$. Relationship between the quality of oral hygiene and caries prevalence was not observed in the present study. Fraiz and Walter ${ }^{8}$ (2001) and Santos and Soviero ${ }^{18}$ (2002) observed a relationship between the presence of caries lesions and the amount of biofilm visible without the use of disclosing agents in children younger than 36 months old. These results can be explained by the methodological differences and by the fact that, although the population examined in this study presented great amount of bacterial biofilm, it may not contain cariogenic bacteria.

Among the socioeconomic variables, when only CCL were considered, the economic classification of the children examined and the mother's educational level were significantly different $(\mathrm{p}<0.05)$. A higher prevalence of CCL was associated with a lower economic classification and a lower mother's educational level, confirming the findings of Dini, et al. ${ }^{6}$ (2000). Economically deprived individuals living under less privileged social and environmental conditions, usually have a poorer health behavior and are therefore are more susceptible to diseases, including oral diseases. ${ }^{3}$

According to the parents, in the AFC municipality, only $54.5 \%$ of the children consumed water from the public supply. This is probably the reason why water fluoridation, which has a recognized action to reduce dental caries ${ }^{5}$, did not showed a statistical significance in the present study.

The use of fluoridated dentifrice did not determine a lower caries prevalence, which might be explained by the time that the children stay in the daycare center, without brushing their teeth. Furthermore, most parents affirmed that they had never been instructed with regards to their children's oral health. Access to dental care did not present a relationship with caries prevalence, corroborating the findings of Cariño, et al. ${ }^{4}$ (2003). Many of the children examined in the present study had never been to the dentist. After completion of data collection, parents and daycare center employees attended lectures about oral health care and dietary habits.

\section{CONCLUSIONS}

Considering the children's age ( $\leq 36$ months old), a high prevalence of dental caries (CCL and ECC) was observed in the present study. Higher prevalence of CCL was associated with lower socioeconomic status, lower mother's educational level and higher duration of breastfeeding. Higher prevalence of ECC was associated with older age group, higher duration of bedtime feeding habit, and later start of oral hygiene. Although the water fluoride content did not show statistical significance with respect to the presence of caries lesions, the children presented a lower caries prevalence in the municipality with adequate fluoride content. Caries prevention strategies on this population should include instructions parents and daycare center employees about oral hygiene, dietary habits, in addition to access to dental care services.

\section{ACKNOWLEDGMENTS}

The authors would like to thank the Education Departments of both municipalities for allowing the conduction of this study, the coordinators and workers of the daycare centers for their cooperation, the parents and children for the participation, and the undergraduate students of the Dental School of Araçatuba, São Paulo State University (UNESP), for their assistance in performing the clinical exams.

\section{REFERENCES}

1- Brandão IMG, Arcieri RM, Sundefeld MLM, Moimaz SAS. Early childhood caries: the influence of socio-behavioral variables and health locus of control in a group of children from Araraquara, São Paulo, Brazil. Cad Saúde Pública. 2006;22:1247-56.

2- Brazil. Health Ministry. National coordination of oral health. SB Brazil 2003 Project. Oral health conditions of the Brazilian population 20022003. Mainly Results [text on the internet]. Brasília; 2004 [cited 2008 Jul 28]. Available from: http://bvsms.saude.gov.br/bvs/publicacoes / projeto_sb2004.pdf

3- Burt BA. Concepts of risk in dental public health. Community Dent Oral Epidemiol 2003;33:240-7.

4- Cariño KM, Shinada K, Kawaguchi Y. Early childhood caries in northern Philippines. Community Dent Oral Epidemiol. 2003;31:81-9.

5- Creedon MI, O'Mullane DM. Factors affecting caries levels amongst 5 -year-old children in County Kerry, Ireland. Community Dent Health. $2001 ; 18: 72-8$

6- Dini EL, Holt RD, Bedi R. Caries and its association with infant feeding and oral health-related behaviours in 3-4-year-old Brazilian children. Community Dent Oral Epidemiol. 2000;28:241-8.

7- Drury TF, Horowitz AM, Ismail AI, Maertens MP, Rozier RG, Selwitz RH. Diagnosing and reporting early childhood caries for research purposes. A report of a workshop sponsored by the National Institute of Dental and Craniofacial Research, the Health Resources and Services Administration, and the Health Care Financing Administration. J Public Health Dent. 1999;59:192-7.

8- Fraiz FC, Walter LRF. Study of the factors associated with dental caries in children who receive early dental care. Pesqui Odontol Bras. 2001;15:201-7.

9- Greene JC, Vermillion JR. The oral hygiene index: a method for classifying oral hygiene status. J Am Dent Assoc. 1960;61:172-9.

10- Gussy MG, Waters EG, Walsh O, Kilpatrick NM. Early childhood caries: Current evidence for aetiology and prevention. J Paediatr Child Health. 2006;42:37-43.

11- Hallett KB, O'Rourke PK. Pattern and severity of early childhood caries. Community Dent Oral Epidemiol. 2006;34:25-35.

12- Marthaler TM, O’Mullane DM, Vrbic V. The prevalence of dental caries in Europe 1990-1995. ORCA Saturday afternoon symposium 1995. Caries Res. 1996;30:237-55. 
13- Milgrom P, Riedy CA, Weinstein P, Tanner AC, Manibusan L, Bruss J. Dental caries and its relationship to bacterial infection, hypoplasia, diet, and oral hygiene in 6- to 36-month-old children. Community Dent Oral Epidemiol. 2000;28:295-306.

14- Mohan A, Morse DE, O'Sullivan DM, Tinanoff N. The relationship between bottle usage/content, age, and number of teeth with mutans streptococci colonization in 6-24-month-old children. Community Dent Oral Epidemiol. 1998;26:12-20.

15- Moimaz SAS, Martins RJ, Forte FDS, Saliba NA. Oral hygiene practices, parents' education level and dental caries pattern in 0 to 5 yearsold children. Braz J Oral Sci. 2005;4:778-82.

16- Rosenblatt A, Zarzar P. Breast-feeding and early childhood caries: an assessment among Brazilian infants. Int J Paediatr Dent. 2004;14:43945

17- Saliba NA, Moimaz SAS, Tiano AVP. Fluoride level in public wate supplies of cities from northwest region of São Paulo state, Brazil. J Appl Oral Sci. 2006;14:346-50.

18- Santos APP, Soviero VM. Caries prevalence and risk factors among children aged 0 to 36 months. Pesqui Odontol Bras 2002;16:203-8.

19- World Health Organization. Oral health surveys: basic methods. 4 ed Geneva: World Health Organization; 1997. 